\title{
The Influence of Relationship Marketing and Service Quality on Customer Satisfaction and Impact on Word of Mouth Customers at the Bank Rakyat Indonesia Tulungagung Branch
}

\author{
Deny Yudiantoro ${ }^{* 1}$, Widji Astuti ${ }^{2}$ and Harianto Respati ${ }^{3}$ \\ ${ }^{1}$ Doctoral Program in Economics Science, University of Merdeka Malang, Indonesia \\ ${ }^{2,3}$ University of Merdeka Malang \\ Indonesia
}

\begin{abstract}
This study aims to analyze the effect of relationship marketing and service quality on word of mouth through customer satisfaction, loan customers at the Bank BRI Branch Tulungagung. This research is quantitative research with the type of research is explanatory research with a survey approach. The sample of this study is the commercial retail loan customers of the UKM sector at the Tulungagung Branch Bank BRI with 1,176 debtors. Based on the analysis method using Structural Equation Modeling, the results of the study show that relationship marketing and service quality affect customer satisfaction and word of mouth. While word of mouth is influenced by customer satisfaction, meaning that satisfaction from borrowing customers will be able to increase positive word of mouth against other prospective borrowers. The results of this study also show that relationship marketing has an effect on word of mouth through customer satisfaction, which means that increasing customer satisfaction will increase word of mouth from customers. The better the ability of bank officers to maintain customer trust, it will make customers provide positive information about the product of the bank concerned to others.
\end{abstract}

Key Words: Relationship marketing, Service quality, Customer satisfaction, Word of mouth.

\section{INTRODUCTION}

Consumer knowledge about various brands or products is more due to the communication formed between consumers themselves. Communication that is easily accepted and understood is communication carried out through oral or direct conversation, which in marketing terms is called word of mouth (Wom). Information obtained from word of mouth communication can reduce information search, because Wom conceptually is the cheapest and simplest advertisement with information delivery in Wom acting as a company promotion agent that has no cost [1]. The Global Consumer Study (2007) shows that in Indonesia included in the ranks of the top five countries that think that word of mouth is the most credible form of advertising. Wom's main goal in saying positive things to other prospective customers, must be proven by the products produced to create customer satisfaction. Customer satisfaction is a person's feelings after consuming or using a company's products. Impressions after consuming or using satisfying products will be informed by customers to other prospective customers [2].

Marketing of service products to produce customer satisfaction, determined by the quality of service delivered to customers. Service quality in service products is not easily determined, because the characteristics of their own service products are diverse, so even though there are service standards, they do not necessarily provide the same quality. Sservice quality is a comparison between the perception of services to be received by customers and the results of service performance received [3].

Companies that achieve competitive advantages needed by customers will be able to increase customer satisfaction. The concept of relational marketing was introduced, explained that relational marketing is "Relationship marketing is a strategy for retention, attraction and enhancement of customer relationships" [4]. Conceptualize relationship marketing has been introduced as the forerunner of effective strategy to attract, sustain and enhance the relationships of customers [5].

Almost the same as other business companies, the banking sector also relies heavily on word of mouth communication in terms of acquiring new customers. Today, the banking sector, such as the Tulungagung Branch of BRI Bank, also faces fierce competition and an unprecedented complex. This is because the number of banks is increasing and technology continues to grow 
in the banking world. The challenges of economic growth which are below the level of 5\% in 2015 and 2016 are also a challenge for the Tulungagung BRI Bank to always be the best in terms of providing quality services and products to customers. In the digital era, the banking challenges are very large, due to the demands of customers who expect banking services to be faster and can be done whenever customers want banking transactions.

The BRI Bank Tulungagung Branch currently has 28 work units spread across all sub-districts, 8 terraces located in the market market in Tulungagung, and also has 2 mobile terraces. Seeing the potential of industry, livestock and trade in Tulungagung Regency, of course BRI has a great opportunity to get as many potential customers as possible, especially from loan customers who have the largest revenue contribution to Bank BRI to date. The basis of a good marketing orientation is strong customer relations and the concept of relationship marketing which is important to be mastered by marketers. Development of relationship marketing research, service quality, customer satisfaction, word of mouth conducted at the BRI Bank Tulungagung Branch.

\section{RESEARCH METHOD}

This research is quantitative research with the type of research is explanatory research with a survey approach, which uses structured instruments in the questionnaire as a data collection tool. The type of data used is the subject data and primary data sources, namely data obtained directly from respondents in the field that comes from the opinions of SME sector commercial retail loan customers at the BRI Bank Tulungagung Branch., about assessments on relationship marketing, service quality, customer satisfaction and word of mouth. The sampling technique in this study is to use a purposive sampling system. This study uses respondents estimated at 170 people, that is, from the multiplication of 10 times the number of parameter estimates (estimated parameter). In this study there are 17 indicators, then 17 X 10 there are 170 respondents, the maximum estimated parameters made are 10. In this study Slovin formula is used because in the withdrawal of 1176 samples, the number must be representative so that the research results can be generalized and the calculation does not require a table of numbers sample. This study uses an interval measurement scale that is measured based on the Likert scale to find out the results of respondents' answers. This study examines the effect of relationship marketing and service quality on customer satisfaction and its impact on word of mouth customers of the retail retail loan BRI Bank Tulungagung Branch.

\section{RESEARCH RESULT}

The results of the research conducted on loan customers at the Tulungagung Branch of BRI Bank, the average value of relationship marketing was 4.19, indicating that respondents' responses tended to strongly agree that emotional society, commitment, trust, handling complaints, communication formed relationship marketing. In service quality variables there are four indicators consisting of service environment, reliability. Interaction quality and empathy. The average value of service quality is 4.00 , indicating that respondents' responses tend to agree that service environment, reliability. Interaction quality, and empathy shape service quality. Customer satisfaction variables are three indicators consisting of repurchase desires, the small desire to file a complaint, proud after using. The results of the average value of customer satisfaction are 4.09, indicating that the responses of respondents tend to strongly agree that the desire to repurchase, the small desire to file complaints, is proud after using shaping customer satisfaction. Word of mouth in word of mouth variable there are five indicators which consist of valence, focus, timing, solicitation and intervention. Based on the average value of word of mouth at 4.24, indicating that the responses of respondents tend to agree that valence, focus, timing, solicitation and intervention form word of mouth.

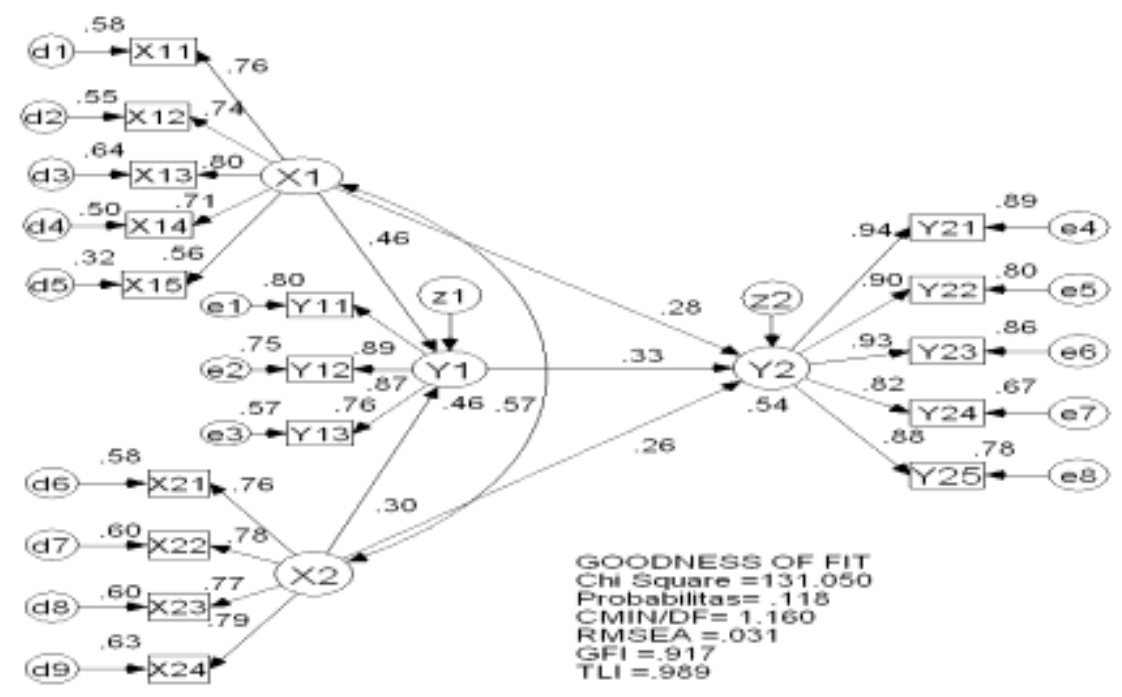

Figure 1. SEM analysis results 
In the normality test of this study the distribution of data follows a diagonal line which means that the observation data is normally distributed. The multicoleration test results show no assumptions of data and data assumptions can be used for the tested model equation structure that was built with the assistance of researchers program AMOS V. 20.

\section{DISCUSSION}

\subsection{The influence of relationship marketing and service quality toward customer satisfaction.}

The results showed that relationship marketing and service quality had an effect on customer satisfaction, but relationship marketing had a greater influence than service quality. this shows that at present customers expect not only product and service excellence, but rather how bank officers establish relationships with customers. Empathy is a dimension forming service quality that is able to create customer satisfaction. When bank officers serve customers both in the office and outside the office, the attitude that must be put forward is empathy. A good bank officer must be able to be four by always listening to customer complaints, giving advice and input on the complaint. Bank officers must be able to make customers feel like priority customers with the attention given individually. Relationship marketing has a positive effect on customer satisfaction [6]. In addition, this study also supports research from Srivastav which states that service quality has a positive effect on customer satisfaction [7].

\subsection{The influence of the relationship marketing and service quality toward word of mouth}

The results of the study show that relationship marketing and service quality affect word of mouth. This means that if the relationship marketing officers' abilities and bank service quality can be improved, positive word of mouth will be formed. Based on the identification of research results indicate that relationship marketing has a greater influence than service quality. At present the customer focus on banking is how customers can feel comfortable with bank officers and feel facilitated in accessing banking services. Pricing issues are not the main determinant in banking competition in Indonesia. The quality of the relationship between bank officers and good customers will be able to reduce the tendency of customers to move to competing bank products.

Positive word of mouth can be created when marketers are able to create good and sustainable quality long-term relationships with customers. Each customer has a different type such as lifestyle, culture, intellectual level, emotions and sensations so that bank officers are required to be communicative in maintaining the trust of customers. The mindset of customers who are critical and rational about a loan product often creates complaints because the customer's expectations are too high and tend to have high inconsistencies. Complaints from these customers should not be ignored regardless of the level and quality of their complaints. If the bank officer ignores the complaint, the customer retention rate will be lost and the customer will provide negative recommendations about the bank's products. The handling of complaints in the form of giving advice and appropriate input will have an impact on the provision of positive information in the form of the superiority of bank transportation products compared to other banks. The results of this study support the research Mousavi, which states that service quality has a positive effect on word of mouth [8]. This study does not agree with Srivastav research which states that service quality has a negative effect on word of mouth [7].

\subsection{The Influence of Customer Satisfaction toward Word of Mouth}

The results show that word of mouth is influenced by customer satisfaction, meaning that satisfaction from borrowing customers will be able to increase positive word of mouth against other prospective borrowers. Positive word of mouth is in the form of recommendations and introduction of bank products carried out by customers to business partners. Customer satisfaction with products and services provided by the bank will lead to positive recommendations for others. It is undeniable that bank income is still dominated by loan interest so that loan productivity greatly affects the business continuity of a bank.

The importance of the role of loans in a bank, credit officials must carefully treat customers. Do not let the loan customers who support the bank's main income feel dissatisfied. Credit officers must always prioritize the interests of customers so that the customers concerned do not feel neglected so that complaints from customers will arise. A small complaint originating from a customer if it is not immediately resolved will trigger the transfer of the customer to another bank. In the credit process, looking for new loan customers with good quality is far more difficult than maintaining old customers. So if there is an old customer who has a loan that has been paid off or is due the bank officer must be able to approach so that the customer wants to borrow again (repeat order). The customer will want to borrow again if the customer concerned is satisfied with the services provided by the credit official. Customers who have paid off more than 3 times have a tendency for customers who are satisfied with bank services, so that the customer not only contributes interest to the bank, but he will invite and will influence many people to borrow at the bank who is the customer partner. .

This kind of marketing pattern will benefit banking companies. Marketing in word of mouth does not require promotional costs from the company. The main key to word of mouth marketing is that, for customers to be satisfied and comfortable with the services provided, customers will contribute to the company in the form of chain marketing that cannot be controlled by the company but can bring more profits. The results of this study support the research Yameng which states that customer satisfaction has a positive effect on word of mouth [9] and disagrees with research from Tahir which states that customer satisfaction has a negative effect on word of mouth [10].

\subsection{The influence of relationship marketing and service quality toward word of mouth through customer satisfaction}

The results of this study indicate that relationship marketing affects word of mouth through customer satisfaction. This means that increasing customer satisfaction will increase word of mouth from customers. The better the ability of bank officers to maintain customer trust, it will make customers provide positive information about the product of the bank concerned to others. 
Today's banking competition is very tight and dynamic, the bank's creative team must not be complacent and easily satisfied with all the results that have been achieved.

The concept of relationship marketing must be well formed in every bank employee. In addition to service and product quality that must be continuously improved, banks must also begin to think about how to form a marketing based that benefits the bank. The closeness between customers and banks can not only be formed from formal performance in the form of services from banks to customers. The emotional closeness that exists can also be formed by non-formal events designed by banks to be given to customers. Family day and gathering with customers is one example of how the bank tries to provide a personal approach to customers who will be able to increase customer trust in the bank.

The results showed that service quality had an effect on word of mouth through customer satisfaction, which meant that improving service quality would have an effect on increasing satisfaction for customers and from satisfied customers there would be word of mouth. The existence of Wom greatly influences consumers to use or not use services offered by banks. In the current digital shield era, the quality of banks is not only seen from a wide range of work units, but also how the behavior of bank officers is always favorable to customers in various conditions. In the current era of digitalization, fast-paced mobility requires the banking sector to accommodate customers' needs, in the form of ease of transactions. When a bank is not ready for changes in the way customers conduct transactions, the bank must be ready to be left by the customer. In this study, customer satisfaction is also due to the reliability of banks in accommodating customer transactions using mobile banking and internet banking. These facilities are the advantages of banks that are used to pamper customers, so that customer satisfaction will be created and eventually a recommendation will be made in the form of positive word of mouth from satisfied customers. The results of this study support the Research Tarokh which states that service quality has a positive and significant effect on word of mouth through customer satisfaction [6].

\section{CONCLUSION}

1) Relationship marketing is formed from several indicators, namely emotional society, commitment, trust, handling complaints, and communication. Bank officers maintain the confidentiality of information from customers is the dominant factor in forming Trusts which is the main indicator of Relationship marketing. Service quality is formed from several indicators, namely service environment, reliability, interaction quality and empathy. The customer response to the highest quality of service is at empathy where the customer always hopes to the bank officer to always give advice and input on the complaints faced. The dimensions of customer satisfaction are formed from the desire to repurchase, the small desire to file a complaint, proud after using. The highest response to customer satisfaction is the desire to repurchase where customers will be willing to continue to use BRI's loan facilities despite an increase in interest rates. Valence, focus, timing, solicitation, intervention dimensions contribute to forming word of mouth. Valence received the highest response with the perception of customers who were willing to invite other people who needed loans to join the same bank as customers.

2) Relationship marketing and service quality are proven to affect customer customer satisfaction, meaning that customers feel satisfaction when bank officers are able to maintain customer trust and are able to provide services to customers when performing services. The results of this study support the research [11], [6], [12], [13], and [7].

3) Relationship marketing and service quality are proven to affect loan customers' word of mouth, meaning that customers will provide recommendations or positive word of mouth when bank officers are able to maintain trust about customer information. With the ability of bank officers to maintain customer trust, the customer will invite other people to use the loan facilities at the same bank as the customer voluntarily. Word of mouth is also formed from the quality of services provided by banks to customers, which are formed by the way the bank's employees work to customers. The results of this study support [14], [15] and $[8]$.

4) Customer satisfaction is proven to affect loan customers' word of mouth, meaning that when customers are satisfied with the services of a bank, customers will give positive word of mouth to others. The results of this study support the Study [16], [17], [18], [19], [20], [21], [22], [23], [13] and [9].

5) Loan customer satisfaction is proven to mediate relationship marketing and service quality towards customer word of mouth behavior. This means that relationship marketing capabilities in the form of the ability to maintain customer trust and service quality in the form of bank officers can be foursome to customers will be able to create word of mouth from customers through satisfaction felt by customers. The results of this study support the [24], [25], [13] and [6].

\section{RECOMMENDATION}

1) Banking players must enrich their knowledge of various studies related to relationship marketing and service quality so that they can become a reference for bank marketers to sell products to customers and always be oriented to customer satisfaction, which will be able to form a sales network through word of mouth communication.

2) This study does not examine the impact of Wom in increasing sales or expanding markets, so it is recommended for other researchers to examine the influence of Wom on increasing sales and also expanding new markets for the company.

3) For other researchers who are then advised to use a variable increase in sales or customer loyalty that is influenced by word of mouth that arises from customer satisfaction. 


\section{REFERENCES}

[1] Sutisna, (2002). Perilaku Konsumen dan Komunikasi Pemasaran. Bandung: Penerbit Remaja Rosdakarya

[2] Kotler, Philip. (2003). Marketing Management, 11-ed.,Pearson Edition International,New Jersey

[3] Parasuraman., V.A, Zeithaml., L.L. Berry. (1988). SERVQUAL: A multiple item scale for measuring consumer perceptions of service quality, Journal of Retailing, 64 (1), p. 12-43.

[4] Berry, L.L. (1983). "Relationship Marketing", in Emerging Perspectives on ServicesMarketing, L.L. Berry, G.L. Shostack and G.D. Upah, Chicago, IL, American MarketingAssociation, p. 25-28.

[5] Ward, Tony ., Tracey, Dagger. (2007). The complexity of relationship marketing for service customers, Journal of Services Marketing, 21/4, p.281-290

[6] Tarokh Jafar, Mohammad. (2015). Recognizing Relationship Marketing Dimensions and Effects on Customer Satisfaction, Loyalty and Word of Mouth Advertisement. MAGNT Research Report (ISSN. 1444-8939)Vol.3 (4). p. 62-86

[7] Srivastav., justin, paul., arun, mittal garima. (2016). Impact of service quality and customer satisfaction on word of mouth in private and public sector banks. International Journal of Bank Marketing, Vol. 34 Iss 5, p. 32-45

[8] Mousavi, Seyed Abbas. (2015). Effect of banking services quality on the customer word of mouth advertising. International journal of economics, commerce and management. Vol. III, Issue 9. p. 318-338

[9] Yameng, Zhu Wenhua., Shi, Lingshu Tang., Xiaohang, Zhang., Yu, Gao. (2016)."How does word of mouth Affect customer satisfaction?". Journal of Business \& Industrial Marketing, Vol. 31 Iss 3, p. 231-276

[10] Tahir, Muhammad. (2013). The Impact of Customer Satisfaction on Word-of-Mouth: Conventional Banks of Malaysia Investigated. International Journal of Information Technology \& Computer Science ( IJITCS ) (ISSN No : 2091-1610 ) Volume 10. p. 84-96

[11] Le Blanc., Nguyen, N., G. (1998). The Mediating Role Of Corporate Image On Customers Retention Decision: An Investigating In Financial Services. International Journal of Bank Marketing. Penerbit Alfabeta.

[12] Kassim, Norizan ., Nor Asiah, Abdullah. (2010). The effect of perceived service quality dimensions on customer satisfaction, trust, and loyalty in e-commerce settings A cross cultural analysis, Asia Pacific Journal of Marketing and Logistics, Vol. 22 No. 3, p. 351-371

[13] Kitapci, Olgun., Ceylan, Akdogan., İbrahim, Taylan Dortyolb. (2014). The Impact of Service Quality Dimensions on Patient Satisfaction, Repurchase Intentions and Word-of-Mouth Communication in the Public Healthcare Industry, Social and Behavioral Sciences, 148 (2014), p $161-169$

[14] Kordnaeij, A., Bakhshizadeh, A., Shabany, R. (2013). "The Outcomes of Relationship Marketing Strategy in Banking Industry by Emphasizing on Word of Mouth", International Research Journal of Applied and Basic Sciences, Vol,4 (7), p.1837-1845

[16] Spreng, Richard A., Gilbert D, Harrell., Robert D. Mackoy. (1995). Service recovery: impact on satisfaction and intentions, Journal Of Services Marketing, VOL. 9 NO. 1, p.15-23

[17] Anderson, E.W. (1998). Customer Satisfaction,Market Share, and Profitability: Findings From Sweden, Journal of Service Research, 1 (1), p. 5-17

[18] Babin, Barry J., (2005), Modeling consumer satisfaction and word-of-mouth: restaurant patronage in Korea, Journal of Services Marketing, 19/3, p.133- 139

[19] Brown., Barry., Dacin., Gunst, (2005). Spreading The Word: Investigating Antecedents of Consumers Positive Word of Mouth Intentions and Behaviors in a retailing Context, Journal the Academy of Marketing Science; Vol. 33. No. 2. p. 123138

[20] Macintosh, Gerrard. (2007). Customer orientation, relationship quality, and relational benefits to the firm, Journal of Services Marketing, 21/3, p.150- 159.

[21] Sweeney, J.C., G.N. Soutar, T. Mazzarol, (2008), Factors influencing word of mouth effectiveness: Receiver perspectives, European Journal of Marketing, 42 (3/4), p. 344-364

[22] Dimitriadis, Sergios . (2010). Testing perceived relational benefits as satisfaction and behavioral outcomes drivers, International Journal of Bank Marketing, Vol. 28 No. 4, p. 297-313

[23] Ha,Young ., Hyunjoo, Im. (2012). Role of web site design quality in satisfaction and word of mouth generation, Journal of Service Management, Vol. 23 No. 1, p. 79-96

[24] Chaniotakis, I.E., Lymperopoulos.C. (2009). Service Quality Effect on Satisfaction and Word of Mouth in the Health Care Industry. Journal of Managing Service Quality, Vol. 19. No. 2. p. 229-242.

[25] Ng, Sandy., Meredith E, David., Tracey S, Dagger. (2011). Generating positive word-of-mouth in the service experience, Journal of Managing Service Quality, Vol. 21 No. 2, p. 133-151. 